\title{
Notes
}

\section{New and Noteworthy Records of Orthoptera and Allies in the Maritimes and the Îles-de-la-Madeleine, Quebec}

\author{
Paul M. Catling ${ }^{1,}{ }^{*}$, Donald F. McAlpine ${ }^{2}$, Christopher I. G. Adam $^{3, \dagger}{ }^{\dagger}$, Gilles Belliveau ${ }^{4}$, Denis \\ Doucet $^{5}$, Aaron D. Fairweather ${ }^{2}$, David Malloch ${ }^{2}$, Dwayne L. Sabine ${ }^{2}$, and A. W. Thomas ${ }^{6}$ \\ ${ }^{1}$ Agriculture and Agri-Food Canada, Environmental Health, Biodiversity, Saunders Building, Central Experimental Farm, \\ Ottawa, Ontario K1A 0C6 Canada \\ ${ }^{2}$ New Brunswick Museum, 277 Douglas Avenue, Saint John, New Brunswick E2K 1E5 Canada \\ ${ }^{3} 65$ Nottingham Street, Fredericton, New Brunswick E3B 4W8 Canada \\ 435 Snowflake Drive, Noonan, New Brunswick E3A9J6 Canada \\ ${ }^{5} 186$ Route 117, Kouchibouguac National Park of Canada, New Brunswick E4X 2P1 Canada \\ ${ }^{6} 595$ Douglas Street, Fredericton, New Brunswick E3E 5T1 Canada \\ *Corresponding author; email: catlingp@agr.gc.ca \\ $\dagger$ Authors 3-9 listed alphabetically
}

Catling, Paul M., Donald F. McAlpine, Christopher I. G. Adam, Gilles Belliveau, Denis Doucet, Aaron D. Fairweather, David Malloch, Dwayne L. Sabine, and A. W. Thomas. 2013. New and noteworthy records of Orthoptera and allies in the Maritimes and the Îles-de-la-Madeleine, Quebec. Canadian Field-Naturalist 127(4): 332-337.

Chortophaga viridifasciata, Forficula auricularia, Melanoplus stonei, Scudderia furcata furcata, Scudderia pistillata, and Trimerotropis verruculata from Prince Edward Island and Doru taeniatum, Melanoplus punctulatus, Orchelimum gladiator, and Spharagemon bolli from New Brunswick are new provincial records. Other records of interest include the endemic Melanoplus madeleineae from Île d'Entrée in the Îles-de-la-Madeleine, Quebec; Trimerotropis verruculata from the Îles-de-la-Madeleine, Quebec; and Chortophaga viridifasciata, Stethophyma lineatum, and Tetrix subulata, new for Cape Breton Island, Nova Scotia. The ranges of Conocephalus brevipennis, Tetrix arenosa angusta, Tetrix ornata, and Tetrix subulata are significantly extended in New Brunswick. A previously unpublished record from 2003 of Roeseliana roeselii (Metrioptera roeselii) is the earliest report of this European introduction to the Maritimes.

Key Words: Chortophaga viridifasciata; Conocephalus brevipennis; Doru taeniatum; Forficula auricularia; Melanoplus madeleineae; Melanoplus punctulatus; Melanoplus stonei; Metrioptera roeselii; Orchelimum gladiator; Roeseliana roeselii; Scudderia furcata; Scudderia pistillata; Spharagemon bolli; Stethophyma lineatum; Tetrix arenosa; Tetrix ornata; Tetrix subulata; Trimerotropis verruculata; new records; Île d'Entrée; Îles-de-la-Madeleine; Quebec; Maritimes; New Brunswick; Prince Edward Island; Nova Scotia; Cape Breton Island

Since the classic works of Vickery et al. (1974), Kevan and Vickery (1977), Vickery and Kevan (1985), and Vickery and Scudder (1987), there have been a number of new records of Orthoptera and allies in various parts of the Maritimes (New Brunswick, Nova Scotia, and Prince Edward Island) and Quebec, including Metrioptera roeselii (Hagenbach), reported by McAlpine (2009) from New Brunswick, and Neoconocephalus retusus, reported by Catling et al. (2009) from Sable Island, Nova Scotia. Newly reported by Scudder and Vickery (2010) are Periplenata brunnea Burmeister established in Nova Scotia; Supella longipalpa (Fabricius), established in Nova Scotia; and Oecanthus nigricornis F. Walker, in New Brunswick. The report of Allonemobius maculatus (Blatchley) by Scudder and Vickery (2010) is thought to be an error, since we know of no records for this species from the Maritimes or Quebec. Chandler (1992) reported the Dusky Cockroach, Ectobius lapponicus (L.), for the first time in Canada from Prince Edward Island. McAlpine and Ogden (2012) reported Conocephalus brevipennis (Scud- der) new to New Brunswick and the Maritimes, Orchelimum gladiator Bruner new to Prince Edward Island and the Maritimes, Neonemobius palustris (Blatchley) new to New Brunswick, Oecanthus nigricornis F. Walker new to Nova Scotia, and Stethophyma lineatum (Scudder) new to New Brunswick.

During 2008-2012, additional new provincial occurrences and other notable range extensions for Orthoptera and allies were recorded, either in the course of field work in the Maritimes and the Îles-de-la-Madeleine, Quebec, or during the examination of collections. New provincial occurrences or other notable range extensions within provinces, including particularly Cape Breton Island (Nova Scotia) and the Îles-de-la-Madeleine (Quebec), are listed alphabetically by species below. The nomenclature follows Orthoptera Species Online (Eades et al. 2013) as well as Vickery and Kevan (1985). Most identifications were made using the latter. Voucher specimens are deposited in the Canadian National Collection of Insects at Agriculture and Agri-Food Canada in Ottawa; the University of Prince Edward 
Island in Charlottetown; the Charlottetown Research Station, Agriculture and Agri-Food Canada, Charlottetown; and the New Brunswick Museum in Saint John.

\section{New provincial records}

\author{
DERMAPTERA \\ New Brunswick \\ Doru taeniatum (Dohrn) \\ Prince Edward Island \\ Forficula auricularia Linnaeus
}

\section{ORTHOPTERA \\ New Brunswick \\ Melanoplus punctulatus punctulatus (Scudder) \\ Orchelimum gladiator Bruner \\ Spharagemon bolli Scudder \\ Prince Edward Island \\ Chortophaga viridifasciata De Geer \\ Melanoplus stonei Rehn \\ Scudderia furcata furcata Brunner von Wattenwyl \\ Scudderia pistillata Brunner von Wattenwyl \\ Trimerotropis verruculata (Kirby)}

\section{Other noteworthy records}

New Brunswick

Conocephalus brevipennis (Scudder)

Roeseliana roeselii (Hagenbach)

Tetrix arenosa angusta Hancock

Tetrix ornata (Say)

Tetrix subulata (Linnaeus)

Îles-de-la-Madeleine, Quebec

Melanoplus madeleineae Vickery and Kevan

Trimerotropis verruculata (Kirby)

Cape Breton Island, Nova Scotia

Chortophaga viridifasciata De Geer

Stethophyma lineatum (Scudder)

Tetrix subulata (Linnaeus)

\section{New provincial records}

\section{DERMAPTERA}

Doru taeniatum (Dohrn)-New Brunswick: Saint John, Saint John Co., 45.2509, -66.1012, 13 November 2010, vegetable produce originating in Mexico, D. Malloch (New Brunswick Museum).

Two live specimens were retrieved from bagged celery originating in Mexico in a local grocery chain. The species is not known to be established in the Maritimes but it is established in southern Michigan, where it occurs in Carex lacustris marshes (Vickery and Kevan 1985). Doru taeniatum has a widespread distribution in the Americas and is easily recognized by the yellowish stripes on the wing covers (Brindle 1971).

Forficula auricularia L.-PRINCE EDWARD ISLAND: Charlottetown, Queens Co., 46.2333, -63.1333, 13
September 1979, M.M. Smith (Agriculture and AgriFood Canada, Charlottetown); Charlottetown, Queens Co., 46.2333, -63.1333, 12 August 1981, L. S. Thompson (Agriculture and Agri-Food Canada, Charlottetown); Holiday Haven, Cornwall, Queens Co., 46.2277, $-63.2182,15$ July 1982, L. S. Thompson (Agriculture and Agri-Food Canada, Charlottetown); Marshfield, Queens Co., 46.3, -63.0833, 9 September 1983, L. S. Thompson (Agriculture and Agri-Food Canada, Charlottetown); Marshfield, Queens Co., dry slope beside graveyard, 46.3086, -63.0503, 19 September 2008, P. M. Catling and B. Kostiuk (Canadian National Collection of Insects); Covehead Road, Route $25,1 \mathrm{~km} \mathrm{~N}$ of Route 220 junction, under building refuse, 46.35344 , -63.11322, 4 October 2010, D. F. McAlpine (New Brunswick Museum); Charlottetown, Queens Co., under rotted wood, $46.240,-63.135,5$ October 2010, D. F. McAlpine (New Brunswick Museum); Bonshaw, Queens Co., 7 May 2011, P. M. Catling (Canadian National Collection of Insects); Kensington, Prince Co., under rotted wood, 46.42916, -63.65323, 12 August 2011, D. F. McAlpine (New Brunswick Museum).

Based on specimens cited above (which are at the Charlottetown Agriculture and Agri-Food Canada Research Station and the New Brunswick Museum), this species was introduced onto Prince Edward Island in the late 1970s and is now well established.

\section{ORTHOPTERA}

Chortophaga viridifasciata De Geer-PRINCE EDWARD IsLAND: $2.7 \mathrm{~km}$ NNE of Caledonia, Kings Co., nymph $1.2 \mathrm{~cm}$ long in open sandy area surrounded by shrubby thickets, 46.0819, -62.6953, 20 August 2008, P. M. Catling and B. Kostiuk (Canadian National Collection of Insects); Shaw Road and Dundas Road, $1.7 \mathrm{~km}$ east of Albion, Kings Co., nymph $1.2 \mathrm{~cm}$ long, dry open Danthonia spicata at edge of blueberry field, 46.34037, -62.46646, 7 May 2011, P. M. Catling and B. Kostiuk (Canadian National Collection of Insects).

Nova Scotia, CAPE BReton Island: Ingonish Centre ball field, Ingonish, Victoria Co., 46.66598, -60.40795, 2 September 2009, P. M. Catling and B. Kostiuk (Canadian National Collection of Insects).

This species overwinters as a nymph. The adults are developed by late May, making it the first grasshopper of the year to appear as an adult. Sometimes during a winter thaw, the nymphs will become active and hop around over melting snow. All new records above are of late summer or spring nymphs.

Melanoplus punctulatus punctulatus (Scudder)-NeW BRUNSWICK: New Brunswick-Quebec border along Route 2, 16. $7 \mathrm{~km}$ NNW of Edmundston, Madawaska Co., Picea mariana forest with scattered Pinus strobus, 47.48691, -68.48336, 22 July 2011, P. M. Catling and B. Kostiuk (Canadian National Collection of Insects); Fredericton (Nashwaaksis), York Co., sidewalk adjacent to small area of mixed woods including Pinus 
resinosa and Pinus strobus, $45.98550-66.64663,14$ September 2012, A.W. Thomas (New Brunswick Museum) (Figure 1).

Usually feeding on pine (Pinus spp.) foliage, this species occurs commonly on trunks late in the season. It was previously recorded in Quebec within $100 \mathrm{~km}$ of the border of northwestern New Brunswick (Vickery and Kevan 1985). Although it is known from the Montreal region and northward, Melanoplus punctulatus punctulatus has not been found previously in the Atlantic Maritime Ecozone (Scudder and Vickery 2010), which includes the eastern townships of Quebec. The new records for New Brunswick are the easternmost.

Melanoplus stonei Rehn- Prince EdWARD IsLAND: Prince Edward Island National Park of Canada, Kings Co., open dunes, 51.06974, $-114.094580,19$ August 2008, P. M. Catling (Canadian National Collection of Insects).

Pale specimens referable to this species were found on the open dunes with only American Beachgrass (Ammophila breviligulata) in Prince Edward Island National Park of Canada near Greenwich on 19 August 2008. They occurred in the same open sandy habitat as pale grey specimens of Dissosteira carolina. Melanoplus stonei is found in the Great Lakes region and southern Manitoba, becoming rare and isolated eastward to New Brunswick and now Prince Edward Island. The distribution suggests that it may be an early postglacial relict dating from a time approximately 10000 years ago, when open sandy habitat was more widespread in the Picea parklands near the front of the continental glacier.

Orchelimum gladiator Bruner- New BRUNSwICK: Callendars Beach, Kouchibouguac National Park of Canada, Kent Co., grass-shrub border adjacent to coast, 46.80732, -64.90716, 18 July 2012, A. Martin and D. Doucet (New Brunswick Museum) (Figure 2); Wilkins Field, Fredericton, York Co., wet meadow, 45.97592, $-66.67515,28$ July 2012, G. Belliveau (New Brunswick Museum); Carleton Park, Fredericton, York

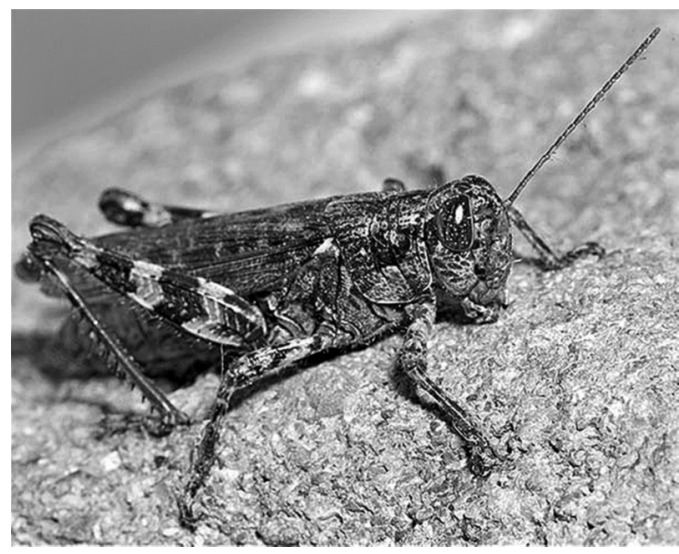

FIGURE 1. Melanoplus punctulatus punctulatus, Fredericton (Nashwaaksis), York County, New Brunswick, 14 September 2012, a species associated with pines. Photo: A. W. Thomas.
Co., tall grasses along Saint John River, 45.96077, -66.62690, 23 August 2012, G. Belliveau (New Brunswick Museum).

McAlpine and Ogden (2012) recorded this species from the Maritimes for the first time (on Prince Edward Island) and suggested it should be widespread in the region. Records above from New Brunswick support this assessment. Perhaps the species is a recent arrival to the region, since it was not recorded during intensive insect surveys carried out in 19771978 in Kouchibouguac National Park of Canada by Agriculture Canada entomologists (Miller and Lyons 1979*).

Scudderia furcata furcata Brunner von WattenwylPRINCE EdWARD Island: near Cherry Hill [Kings Co.], shrubby area beside swamp, 46.3826, $-62.8605,19$ September 2008, P. M. Catling and B. Kostiuk (Canadian National Collection of Insects); N of Wood Island, Highway 4, shrubby roadside, 45.967, -62.7328, 18 September 2008, P. M. Catling and B. Kostiuk (Canadian National Collection of Insects); N of Wood Island [Queens Co.], Highway 4, leatherleaf bog, 45.9673, -62.729, 18 September 2008, P. M. Catling and B. Kostiuk (Canadian National Collection of Insects).

Previously known in the Maritimes from Cape Breton Island (Nova Scotia) and mainland Nova Scotia.

Scudderia pistillata Brunner von Wattenwyl- PRINCE EDWARD ISLAND: Flat River [Queens Co.], 46.0071, $-62.8575,2$ September 1953, J. White (University of Prince Edward Island); Cardigan [Kings Co.], 46.2331, -62.6187, 27 September 1953, F. McLeod (University of Prince Edward Island); Belmont [Prince Co.], 46.4832, -63.8163, 30 September 1956 (University of Prince Edward Island); St. Eleanors [Prince Co.], ECB pheromone trap, 46.4166, -63.8166, 11 August 1988, J. G. Stewart (Charlottetown Research Station, Agriculture and Agri-Food Canada); Southside, ECB pheromone trap, 23 August 1990, M. E. M. Smith

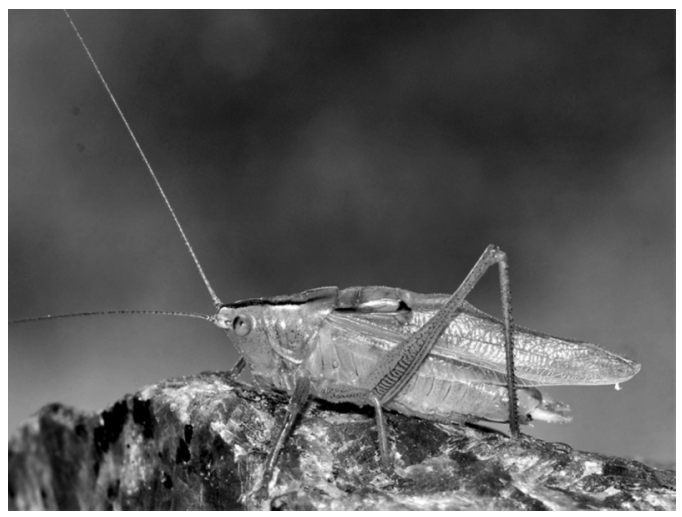

FIgURE 2. Orchelimum gladiator, Callendars Beach, Kouchibouguac National Park of Canada, Kent County, New Brunswick, netted by Park visitor A. Martin on 18 July 2012 during a public "bioblitz" organized by the Park. Photo: D. Doucet. 
(Charlottetown Research Station, Agriculture and AgriFood Canada); Blooming Point [Queens Co.], 46.4052, $-62.9598,23$ July 2008, P. M. Catling and B. Kostiuk (Canadian National Collection of Insects); Driftwood Cottages near Tignish [Prince Co.], 25 July 2008, P. M. Catling and B. Kostiuk (Canadian National Collection of Insects); near Burnt Point [Kings Co.], saltmarsh, 46.17922, -62.51176, 27 July 2008, P. M. Catling and B. Kostiuk (Canadian National Collection of Insects); Highway 113, Cardigan Road, 46.29538, -62.62018, 10 August 2009, P. M. Catling and B. Kostiuk (Canadian National Collection of Insects).

Previously known from New Brunswick and from Cape Breton Island (Nova Scotia) and mainland Nova Scotia.

Spharagemon bolli Scudder- New BRUNSWICK: $2 \mathrm{~km}$ W of St. George, Charlotte Co., open rock on open hilltop dominated by blueberry, $45.13682,-66.85981,9$ August 2009, P. M. Catling and B. Kostiuk (Canadian National Collection of Insects).

Previously known from southwestern Maine and Quebec adjacent to northwestern New Brunswick (Vickery and Kevan 1985), this species was found in open rock and gravel on an open hilltop dominated by blueberry.

Trimerotropis verruculata (Kirby) - PRINCE EDWARD IsLAND: Highway $12 \mathrm{~W}$, clearcut beside old sand pit, $4 \mathrm{~km} \mathrm{~S}$ of Doyle Road, 46.968, -64.0055, 25 July 2008, P. M. Catling and B. Kostiuk (Canadian National Collection of Insects); open shrubby areas of back dunes at Cedar Dunes Provincial Park, West Point [Prince Co.], 46.6201, -64.38615, 26 July 2008, P. M. Catling and B. Kostiuk (Canadian National Collection of Insects); Georgetown [Kings Co.] lumber yard, 46.19252, $-62.53757,27$ July 2008, P. M. Catling and B. Kostiuk (Canadian National Collection of Insects); Wood Islands ferry [Queens Co.], edge of parking lot, 45.95481, $-62.74798,27$ July 2008, P. M. Catling and B. Kostiuk (Canadian National Collection of Insects); Murray Road, dry sandy area with blueberry, 45.9821, -62.7176, 18 September 2008, P. M. Catling and B. Kostiuk (Canadian National Collection of Insects); Little Harbour [Kings Co.], Road 303, sand pit, 46.3677, -62.189, 19 September 2008, P. M. Catling and B. Kostiuk (Canadian National Collection of Insects); near Glencorradale [Kings Co.], two-year-old clearcut, 46.413, -62.2285, 20 September 2008, P. M. Catling and B. Kostiuk (Canadian National Collection of Insects).

QueBeC, ÎLES-DE-LA-MADELEINE: Îles de la Madeleine, ferry terminal, Cap-aux-Meules, 47.38259, -61.8589 , 12 August 2009, P. M. Catling and B. Kostiuk (Canadian National Collection of Insects); Îles de la Madeleine, Cap-aux-Meules pit, 47.36505, -61.91158, 14 August 2009, P. M. Catling and B. Kostiuk (Canadian National Collection of Insects); Îles de la Madeleine, Butte de la Croix, 47.23705, -61.85708, 14 August 2009, P. M. Catling and B. Kostiuk (Canadian National Collection of Insects); Îles de la Madeleine, HavreAubert, chemin du Sable, 47.22147, -61.0321, 14
August 2009, P. M. Catling and B. Kostiuk (Canadian National Collection of Insects); Île du Havre aux Maisons, open, dry, sandy heathland beside airport, Empetrum dominant, 47.42017, -61.78595, 11 August 2010, P. M. Catling and B. Kostiuk (Canadian National Collection of Insects); Île du Havre aux Maisons, Butte sur Mer, open rocky hilltop, Danthonia dominant, 47.39261, -61.77411, 11 August 2010, P. M. Catling and B. Kostiuk (Canadian National Collection of Insects); Île d'Entrée, sandy and stony beach at dock, 47.27683, -61.71788, 14 August 2010.

This species was expected but likely overlooked previously on Prince Edward Island. This may have been due to the limited habitat available. Habitat includes open gravelly or sandy areas and exposed substrate of burns, where the species is active and conspicuous only in warm, sunny weather. Although Trimerotropis verruculata is found in several places in the Îles-de-la-Madeleine, there is a possibility that it has recently been introduced there, since it was not recorded in an earlier survey (Kevan and Vickery 1977) and its crepitation can be heard over a distance of almost $1 \mathrm{~km}$. It is hard to imagine that Kevan and Vickery missed it.

\section{Other noteworthy Orthoptera records}

Conocephalus brevipennis (Scudder)-New BRUNSwICK: Douglas, York Co., grassy ditch along road, 45.99985, -66.7644, 7 October 2012, D. L. Sabine (New Brunswick Museum).

McAlpine and Ogden (2012) reported this species from the Maritimes for the first time, based on specimens collected in Queens County, New Brunswick, in 2008 and 2011. They suggested that the species had previously been overlooked but that records were too few to assess distribution or status. Here we add York County to the New Brunswick distribution. Our knowledge of the status of this species in the Maritimes remains scanty.

Roeseliana roeselii (Hagenbach) - New BRUNSWICK: eastern end of Princess Margaret Bridge, Fredericton, York Co., periodically mowed right-of-way, 45.94316, $-66.61769,19$ July 2003, D. L. Sabine (New Brunswick Museum); Fredericton, York Co., approximately 45.92, -66.64, 15 July 2006, C. Adam (Figure 3, photo

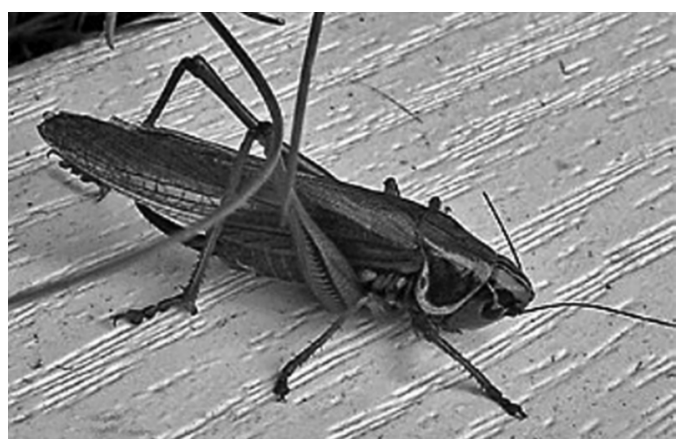

FIgURE 3. A photo record of Roeseliana roeselii taken at Fredericton, York County, New Brunswick, on 15 July 2006 that pre-dates the previous first published report in McAlpine (2009). See text for a still earlier record. Photo: C. Adam. 
only); approximately $4.5 \mathrm{~km} \mathrm{NW}$ of Riverside-Albert, Caledonia Gorge Protected Natural Area, Albert Co., $45.77734-64.78674$ and $45.77267-64.78485,20$ and 21 August 2012, old-field habitat, open woods road verge, A. A. D. Fairweather, D. F. McAlpine (New Brunswick Museum).

This species, called Metrioptera roeselii by Vickery and Kevan (1985), is evidently very well established in New Brunswick, having been previously reported in Charlotte, Saint John, Queens, and Kent counties (McAlpine 2009; McAlpine and Ogden 2012). Here we add Albert County, in the Caledonia Gorge Protected Natural Area, and York County. Although this species was previously first recorded in the Maritimes in 2009, specimen and photo records included here from 2003 and 2006, combined with the rapid accumulation of records supporting a wide distribution in the province, suggest that $R$. roeselii was probably present in the Maritimes well before 2003. Based on collections from the Caledonia Gorge Protected Natural Area, this species will readily colonize oldfield habitat even in areas otherwise heavily forested.

Melanoplus madeleineae Vickery and Kevan-QuEBEC, ÎLEs-De-LA-Madeleine: Île du Havre aux Maisons, northeast corner, Carex-Juncus-Eupatorium wetland among hills overlooking Dune du Sud and Île d'Entrée, 47.4069, -61.765, 11 August 2010, P. M. Catling and B. Kostiuk (Canadian National Collection of Insects) (Figure 4); Île du Havre aux Maisons, hillslope on Butte Ronde, dead on the road, 47.39495, -61.77286, 13 August 2010, P. M. Catling and B. Kostiuk (Canadian National Collection of Insects); Île d'Entrée, start of path to Big Hill, open acidic rocks and

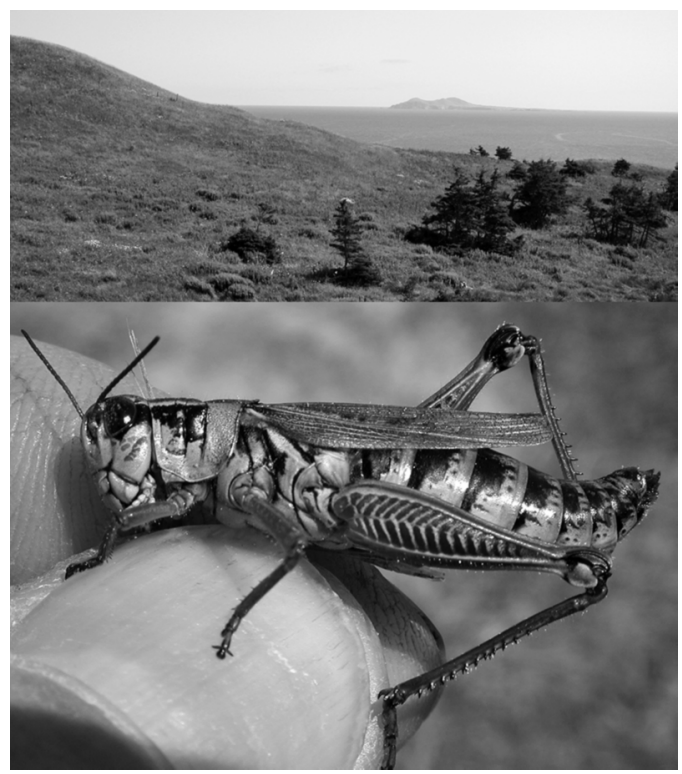

Figure 4. Melanoplus madeleineae. Above, open meadow habitat on Île du Havre aux Maisons in the Îles-dela-Madeleine, Quebec, with Île d'Entrée in the background on 11 August 2010. Below, female Melanoplus madeleineae on 11 August 2010. Photos: P. M. Catling. path edge, stepped on by hiker, $47.27649,-61.70073$, 14 August 2010, P. M. Catling and B. Kostiuk (Canadian National Collection of Insects).

Any records of this uncommon and evidently taxonomically acceptable (Chapco and Litzenberger 2002) endemic (not to be confused with $M$. magdalenae of the Magdalena Mountains of New Mexico) are of interest. Previously it was found only on islands of the main chain of the Îles-de-laMadeleine. Île d'Entrée is separated from the rest of the group by $4.8 \mathrm{~km}$ of ocean. In 2009 and 2010, only three females were found (listed above) from a search of more than 50 localities (separated by $1 \mathrm{~km}$ ) throughout the islands, including Île Brion. Although the surveys were conducted in August when this possibly early grasshopper might have occurred in decreased numbers, there is also a possibility that it has declined due to habitat loss, increased traffic on roads and paths, and predation by introduced [European] Starlings [(Sturnus vulgaris)]. Flocks of [European] Starlings are abundant, and they are efficient predators of grasshoppers on the islands (P. M. Catling, personal observation). Remains of $M$. madeleineae were found in regurgitated pellets of Whimbrel [(Numenius phaeopus)] on Grosse Île.

Stethophyma lineatum (Scudder)-Nova ScOtIA, CAPE BRETON Island: $15 \mathrm{~km}$ NE of Baddeck [Victoria Co.], marshy ditch, 5 September 2009, P. M. Catling and B. Kostiuk (Canadian National Collection of Insects).

Since it was already known from mainland Nova Scotia, Prince Edward Island, and the island of Newfoundland in Newfoundland and Labrador, the occurrence of Stethophyma lineatum on Cape Breton Island (Nova Scotia) was anticipated. McAlpine and Ogden (2012) recently reported this species for the first time at two localities in New Brunswick, but overlooked an earlier unpublished report from Kouchibouguac National Park (Miller and Lyons 1979*).

Tetrix arenosa angusta, Hancock-New BRUNSWICK: Grand Bay-Westfield, Kings Co., sparsely vegetated ground, 45.3406, -66.2539, 8 September 2008, D. F. McAlpine (New Brunswick Museum).

Known previously in New Brunswick from a single record from York County (probably Fredericton) (Vickery and Kevan 1985).

Tetrix ornata (Say)-New BRUnSwicK: Menneval, Restigouche Co., 47. 80747, -67.17541, 17 June 1964, G. G. E. Scudder (Canadian National Collection of Insects); Saint John, 45.27, -66.07, Saint John Co., 4 June 1899, W. McIntosh (New Brunswick Museum); Saint John, approximately 45.27, -66.07, Saint John Co., 9 June 1901, W. McIntosh (New Brunswick Museum) Crooked Creek bridge, Caledonia Gorge Protected Natural Area, vegetated roadside, 45.79684, -64.77653, A. A. D. Fairweather (New Brunswick Museum, no date).

Vickery and Kevan (1985) map a single record for this species, from northwestern New Brunswick in the KentNorthumberland counties border region. Historical collections in the New Brunswick Museum and the Canadian National Collection of Insects and a recent collection from the Caledonia Gorge Protected Natural Area add Restigouche County, Saint John County, and Albert County, together suggesting a wide distribution in the province. 
Tetrix subulata (Linnaeus)-NeW BRUNSWICK: Saint John, 45.27, -66.07, Saint John Co., 2 June 1898, $W$. McIntosh (New Brunswick Museum); Saint John, 45.27, -66.07, Saint John Co., 1 May 1899, W. McIntosh (New Brunswick Museum).

Nova Scotia, CAPE Breton Island: an old sand pit at South Harbour [Victoria Co.], 46.86618, -60.46291, 2 September 2009, P. M. Catling and B. Kostiuk (Canadian National Collection of Insects).

Vickery and Kevan (1985) map this species from various localities in western New Brunswick and the extreme northeastern corner of the province. The historical records below appear to be the first from Saint John County and confirm a widespread distribution for this species in New Brunswick, at least historically. Considering the widespread distribution of the species in the Maritimes generally (Vickery and Kevan 1985), the presence of T. subulata on Cape Breton Island, Nova Scotia, was expected.

\section{Acknowledgements}

A. Martin and B. Kostiuk assisted with field work.

Documents Cited (marked * in text)

Miller, S. J., and D. B. Lyons. 1979. An entomological survey of Kouchibouguac National Park. Unpublished report, Biosystematics Research Institute, Agriculture Canada, Ottawa.

\section{Literature Cited}

Brindle, A. 1971. A revision of the genus Doru, Dermaptera: Forficulidae. Papeis Avulsos do Departamento de Zoologia (Sao Paulo). 23(21). 1971. 173-196.

Catling, P. M., Z. Lucas, and B. Freedman. 2009. Plants and animals new to Sable Island, Nova Scotia. Canadian Field-Naturalist 123(2): 141-145.

Chandler, D. S. 1992. New records of Ectobius lapponicus in North America (Dictyoptera: Blattellidae). Entomological News 103(4): 139-141.
Chapco, W., and G. Litzenberger. 2002. A molecular phylogenetic study of two relict species of melanopline grasshoppers. Genome 45: 313-318.

Eades, D. C., D. Otte, M. M. Cigliano, and H. Braun. 2013. Orthoptera Species File Online. http://orthoptera.spe ciesfile.org/HomePage/Orthoptera/HomePage.aspx.

Kevan, D. K., and V. R. Vickery. 1977. The orthopteroid insects of the Magdalen Islands with notes from adjacent regions. Annals of the Entomological Society of Quebec 22: 193-204.

McAlpine, D. F. 2009. First occurrence of Roesel's Bush Cricket, Metrioptera roeselii, (Hagenbach), (Orthoptera: Tettigoniidae), in New Brunswick. Journal of the Acadian Entomological Society 5: 1-2.

McAlpine, D. F., and J. B. Ogden. 2012. New and noteworthy records of Orthoptera from Maritime Canada. Journal of the Acadian Entomological Society 8: 43-47.

Scudder, G. G. E., and V. R. Vickery. 2010. Chapter 17. Grasshoppers (Orthoptera) and allied insects of the Atlantic Maritime Ecozone. Pages 371-379 in Assessment of Species Diversity in the Atlantic Maritime Ecozone. Edited by D. F. McAlpine and I. M. Smith. NRC Research Press, Ottawa, Ontario. 785 pages.

Vickery, V. R., and D. K. M. Kevan. 1985. The grasshoppers, crickets, and related insects of Canada and adjacent regions-Ulonata: Dermaptera, Cheleutoptera, Notoptera, Dictuoptera, Grylloptera, and Orthoptera. Part 14 of The Insects and Arachnids of Canada. Agriculture Canada Research Branch Publication 1777. Agriculture Canada, Ottawa, Ontario. 918 pages.

Vickery, V. R., and G. G. E. Scudder. 1987. The Canadian orthopteroid insects summarized and updated, including a tabular check-list and ecological notes. Proceedings of the Entomological Society of Ontario 118: 25-45.

Vickery, V. R., D E. Johnstone, and D. K. M. Kevan. 1974. The orthopteroid insects of Quebec and the Atlantic provinces of Canada. Lyman Entomological Research Museum and Research Laboratory Memoir No. 1 (Special Publication No. 7). 204 pages.

Received 16 November 2012

Accepted 12 July 2013 